\title{
ADVANCES IN DIAGNOSIS AND TREATMENT OF HELICOBACTER PYLORI INFECTION
}

\author{
REZA RANJBAR $^{1}$, PAYAM BEHZADI ${ }^{2}$ and SHOHREH FARSHAD ${ }^{3 *}$ \\ ${ }^{1}$ Molecular Biology Research Center, Baqiyatallah University of Medical Sciences, \\ Tehran, Iran \\ ${ }^{2}$ Department of Microbiology, College of Basic Sciences, Shahr-e-Qods Branch, Islamic \\ Azad University, Tehran, Iran \\ ${ }^{3}$ Clinical Microbiology Research Center, Shiraz University of Medical Sciences, \\ Shiraz, Iran
}

(Received: 31 July 2016; accepted: 25 November 2016)

\begin{abstract}
Helicobacter pylori is a Gram-negative motile bacterium causative agent of acute and chronic digestive and extra-digestive human infections. According to different reports worldwide, H. pylori symptomatic and asymptomatic infections are a global problem. The statistical investigations show a percentage of 50 for people who are involved in $H$. pylori acute/chronic digestive and/or extra-digestive infections around the world. This review focuses on digestive and extra-digestive diseases caused by $H$. pylori, the related virulence factors, diagnostic techniques including noninvasive and invasive diagnostics and treatment. There is an abundance of diagnostics for detection and identification of $H$. pylori. The availability, cost, and the condition of test performance may differ from place to place. To increase the level of reliability in association with diagnostic tools for detecting $H$. pylori, several techniques must be applied at once as multi-diagnostic technique. Furthermore, there are several pharmacotherapies which can be used for complete eradication of $H$. pylori infection.
\end{abstract}

Keywords: Helicobacter pylori, diagnostic techniques, treatment

\section{Introduction}

Helicobacter pylori is a curved motile Gram-negative spiral bacterium, which has been isolated from gastritis patients by Australian scientists Marshall and Warren in 1983. The unipolar flagellum makes the bacterium highly motile for quick movements and attachments to gastric mucosa. According to some studies, H. pylori is naturally able to colonize on the surface of gastroduodenal mucosa of human beings, a relationship with a background of near 60,000 years old [1-11].

\footnotetext{
*Corresponding author; E-mails: s_farshad@yahoo.com, farshads@sums.ac.ir
} 
H. pylori is an important bacterial infectious agent that causes significant gastrointestinal tract (GIT) and extra-digestive infections worldwide. Infections caused by $H$. pylori are more frequent in overcrowded populations with low hygiene $[3,4,12,13]$.

The recorded reports from different countries show that approximately $50 \%$ of people are infected by $\mathrm{H}$. pylori around the world. The coverage system relating to high urease activity enables $H$. pylori to survive in acidic condition of stomach. The powerful ureolytic activity of cytoplasmic urease produced by H. pylori catalyses the conversion of gastric juice urea into alkaline ammonia and carbon dioxide which is produced in stomach [5-7, 14-22].

The majority of patients with $H$. pylori GIT infections have no significant clinical gastric involvement and sometimes there are asymptomatic patients. However, chronic gastric inflammation or gastritis is the predominant clinical symptom in association with $H$. pylori digestive infections and it is known as a risk factor in patients with GIT diseases including gastric mucosa in association with lymphoid tissue (MALT) lymphoma, gastric cancer (GC) and adenocarcinoma, gastroesophageal reflux disease, and duodenal ulcers (DU). Complete eradication of $H$. pylori by antibiotics may lead to definitive treatment of early MALT lymphoma. Previous studies indicate a close association between infections caused by $H$. pylori and GC [5, 6, 19, 21, 23-32].

Mostly, people acquire digestive and extra-digestive $H$. pylori infections in their childhood and without any antibiotic therapy they may be carried in an individual's whole life [29].

There are many extra-digestive diseases and infections including autoimmune diseases, bronchiectasis, cardiovascular diseases, colonic and pancreatic diseases, diabetes mellitus, hepatobiliary system diseases, neurological diseases, skin diseases, and hematological diseases that are in association with $H$. pylori (Table I) [13, 30, 32-42].

In the present review, we show the digestive and extra-digestive infections and diseases caused by $H$. pylori, the related virulence factors, diagnostic techniques including non-invasive and invasive diagnostics and treatment.

\section{Virulence Factors in Digestive and Extra-digestive Pathogenic Strains of H. pylori}

Adhesion is the most important factor for colonization of microorganisms. In consequence, colonization of microbial populations including $H$. pylori may lead to translocation of virulence factors from pathogen into host cell and facilitate the persistence of infection. Thus there are several genes that play 
Table I. Extra-digestive diseases and their subgroups caused by $H$. pylori

\begin{tabular}{ll}
\hline $\begin{array}{l}\text { Extra-digestive group } \\
\text { diseases }\end{array}$ & \multicolumn{1}{c}{ Subgroups of diseases } \\
\hline Autoimmune diseases & $\begin{array}{c}\text { Autoimmune thyroid disease (ATD), Grave's disease, rheumatoid arthritis, } \\
\text { Crohn's disease, Behcet's disease }\end{array}$ \\
Cardiovascular diseases & $\begin{array}{c}\text { Atherosclerotic plaques, ischemic heart disease, Coronary artery disease, } \\
\text { stroke } \\
\text { Colorectal cancer, colorectal adenoma, colorectal adenocarcinoma, GC }\end{array}$ \\
$\begin{array}{c}\text { Colonic and pancreatic } \\
\text { diseases }\end{array}$ & $\begin{array}{c}\text { Non-alcoholic fatty liver disease, cirrhosis, hepatic encephalopathy, liver } \\
\text { fibrosis, hepatocellular carcinoma, cholangiocarcinoma } \\
\text { diseases } \\
\begin{array}{l}\text { Neurological diseases } \\
\text { Skin diseases }\end{array} \\
\begin{array}{c}\text { Dementia, Alzheimer disease, multiple sclerosis, neuromyelitis optica } \\
\text { Chronic urticaria, chronic facial dermatosis (rosacea), psoriasis vulgaris, }\end{array} \\
\text { Hematological diseases } \\
\text { Henoch-Schönlein purpura, alopecia areata, Sweet's syndrome } \\
\text { Iron deficiency anemia, pan gastritis, idiopathic thrombocytopenic purpura } \\
\text { (ITP) }\end{array}$ \\
\hline
\end{tabular}

important role as virulence factors in different pathogenic strains of $H$. pylori (Table II) [21, 30, 43-52].

Genetic studies have corroborated the presence of cag pathogenicity island (cag PAI) in the pathogenic strains of H. pylori. The cag PAI is a 40,000 bp chromosomal DNA segment which is made up of 31 genes and divided into cag I and cag II [21, 30, 47, 53-55].

The pathogenic strains of $H$. pylori causing digestive and extra-digestive diseases encompass cag PAI. Therefore, $H$. pylori bacteria are divided into two groups of $\operatorname{cag} A$-positive and $\operatorname{cag} A$-negative strains. The $\operatorname{cag} E$ has intensive correlation with $\operatorname{cag} A$ and both genes contribute in digestive and extra-digestive diseases [21, 30, 56-61].

The vacA gene is detected in all strains of $H$. pylori and three alleles including $\mathrm{s}$ (signal), $\mathrm{i}$ (intermediate), and $\mathrm{m}$ (middle) are recognized for it. The $v a c A$ gene is responsible for longevity of $H$. pylori infection [21, 30, 47-50, 61].

The $\operatorname{dup} A$, the DU promoting gene placed in malleability part of the genome of $\mathrm{H}$. pylori is known as a bipartite sequence consisted of two genes of jhp0917 and jhp0918.

The ice $A$ gene is induced by contact with epithelium possesses the allelic variants of iceA1 and iceA2. The iceA1 and NlaIIIR (a gene detected in Neisseria lactamica encoding a type of restricted enzyme which act in CTAG specific sequence) genes have an ambient homology with each other. The activity of iceA2 is unknown $[30,61]$.

The $b a b$ alleles involving $b a b A 1, b a b A 2$, and $b a b B$ are known as blood group antigen binding genes. The $b a b A 2$ may be expressed with $c a g A$ and $v a c A$ genes and among its alleles, e.g., $b a b A 1$ and $b a b B$ have a key role in pathogenesis [30, 62]. 
Table II. The relationship between virulence factor genes, their functions, and phenotypic manifestations

\begin{tabular}{|c|c|c|c|c|}
\hline Genes & Protein & Properties & Function & $\begin{array}{c}\text { Phenotypic } \\
\text { manifestations }\end{array}$ \\
\hline $\operatorname{cag} A$ & CagA & Oncoprotein & $\begin{array}{l}\text { Formation of bacterial } \\
\text { type IV secretion system, } \\
\text { Triggering } \\
\text { IL-6 production }\end{array}$ & $\begin{array}{l}\text { Gastric inflammation- } \\
\text { associated diseases } \\
\text { (GIAD), peptic ulcer } \\
\text { diseases (PUD), GC, } \\
\text { cardiovascular } \\
\text { disease, ATD, ITP, } \\
\text { hepatobiliary system } \\
\text { diseases, colonic and } \\
\text { pancreatic diseases }\end{array}$ \\
\hline $\operatorname{cag} E$ & CagE & Cytokine inducer & $\begin{array}{l}\text { Triggering IL- } 1 \beta \text { and } \\
\text { IL- } 8 \text { production }\end{array}$ & $\begin{array}{l}\text { PUD, hepatobiliary } \\
\text { system diseases }\end{array}$ \\
\hline$v a c A$ & VacA & $\begin{array}{l}\text { Vacuolating } \\
\text { cytotoxin }\end{array}$ & $\begin{array}{l}\text { Epithelial cell vacuolation, } \\
\text { induction of channels in } \\
\text { cell membrane, release } \\
\text { of mitochondrial } \\
\text { cytochrome c, } \\
\text { suppressing T-cell } \\
\text { responses }\end{array}$ & $\begin{array}{l}\text { GIAD, PUD, GC, } \\
\text { hepatobiliary system } \\
\text { diseases }\end{array}$ \\
\hline dupA & DupA & $\begin{array}{l}\text { Duodenal ulcer } \\
\text { promoting gene }\end{array}$ & $\begin{array}{l}\text { Formation of bacterial } \\
\text { type IV secretion system, } \\
\text { triggering IL- } 8 \\
\text { production }\end{array}$ & $\begin{array}{l}\text { GC, dyspepsia, PUD } \\
\text { such as DU }\end{array}$ \\
\hline $\begin{array}{l}i c e A \\
\quad(\text { iceA1, } \\
\text { iceA2) }\end{array}$ & IceA & $\begin{array}{l}\text { Producing via } \\
\text { bacterial contact } \\
\text { with gastric } \\
\text { epithelial cells }\end{array}$ & $\begin{array}{l}\text { Triggering IL-8 } \\
\text { production }\end{array}$ & $\begin{array}{l}\text { Asymptomatic gastritis, } \\
\text { dyspepsia, PUD such } \\
\text { as DU, GC, } \\
\text { hepatobiliary system } \\
\text { diseases }\end{array}$ \\
\hline $\begin{array}{l}b a b \\
\quad(b a b A 1 \\
b a b A 2 \\
b a b B)\end{array}$ & $\begin{array}{l}\text { BabA1, } \\
\text { BabA2, } \\
\text { BabB }\end{array}$ & Adhesin & $\begin{array}{l}\text { Binding activity to } \\
\text { blood group antigens } \\
\text { (H. pylori tropism } \\
\text { mechanism) }\end{array}$ & $\begin{array}{l}\text { PUD such as DU, } \\
\text { intestinal metaplasia, } \\
\text { hepatobiliary system } \\
\text { diseases, GC }\end{array}$ \\
\hline$s a b A$ & SabA & Adhesin & $\begin{array}{l}\text { Binding to sialylated } \\
\text { glycans on the surface of } \\
\text { host epithelial and red } \\
\text { blood cells, inducing } \\
\text { phagocytosis }\end{array}$ & GIAD, GC \\
\hline oipA & $\begin{array}{l}\text { OipA/ } \\
\text { HopH }\end{array}$ & $\begin{array}{l}\text { Pro-inflammatory } \\
\text { outer membrane } \\
\text { protein }\end{array}$ & $\begin{array}{l}\text { Triggering IL-8 } \\
\text { production }\end{array}$ & GIAD, PUD such as DU \\
\hline
\end{tabular}

The $s a b A$, a sialic acid binding adhesion gene has an effective role in adherence of $H$. pylori to the host cells [30].

The oipA, the gene of outer inflammatory protein has a strong correlation with other virulent genes including $\operatorname{cag} A$, ice $A$, and vacA. oip $A$ is an active gene in H. pylori pathogenesis [30]. 
Table III. The relationship among host predisposing factor, type of predisposing factor, and phenotypic demonstration

\begin{tabular}{|c|c|c|}
\hline Host predisposing factors & Type of predisposing factor & Phenotypic demonstration \\
\hline \multirow[t]{3}{*}{ Gene polymorphism } & $\begin{array}{l}\text { Polymorphic antagonist genes of } \\
\text { interleukin-1 } \beta \text { (IL-1 } \beta) \text { and IL-1 } \\
\text { receptors }\end{array}$ & $\begin{array}{l}\text { Raising the progression of } \\
\text { GC up to } 2-3 \text { times }\end{array}$ \\
\hline & $\begin{array}{l}\text { Polymorphic regulator genes of tumor } \\
\text { necrosis factor- } \alpha \text { and IL- } 8 \text {, IL-16 }\end{array}$ & $\begin{array}{l}\text { Raising the progression of } \\
\text { GC significantly }\end{array}$ \\
\hline & $\begin{array}{l}\text { Polymorphic receptors belonging to the } \\
\text { innate immune system }\end{array}$ & \\
\hline
\end{tabular}

The sextette genes including babA, babB, hopZ, oipA, sabA, and $s a b B$ encode for the outer membrane proteins that are closely correlated with gastroduodenal lesions and infections via bacterial adhesion. The aforementioned genes are variable in different strains of $H$. pylori [21, 43, 63-65].

Furthermore, enzymes including catalase, lipase, phospholipase, protease, and urease are influent virulence factors in the pathogenesis of $H$. pylori strains [38].

In addition to $H$. pylori virulence factors, there are several genetic factors in human hosts that predispose the digestive and extra-digestive infections and diseases (Table III).

Moreover, the environmental predisposing factors including salt, vinegar, alcohol, and smoke trigger the progression of GC [12, 13, 30, 34, 59, 66, 67].

\section{Diagnostic Techniques}

There are several available diagnostic procedures which are categorized into two major groups of non-invasive (without endoscopy) and invasive (with endoscopy) tests. The aforementioned tests are used for detecting digestive and extra-digestive infections and diseases caused by pathogenic strains of $H$. pylori; however, the non-invasive tests are more usual for diagnosing extra-digestive diseases [38, 68-72].

All of the tests including non-invasive and invasive are reliable and accurate, but each one has its limitations. Thus, there is a huge lack of single test as Gold Standard and optimal diagnostic technique. The only way to increase reliability of diagnosis is to apply for a multi-diagnostic tool [70, 73-75].

According to recent studies, for improving diagnostic tests and managing treatments, all individuals with DU disease must be checked via clinical tests before antibiotic therapy. Testing program is a proper strategy for diagnosing and 
managing $H$. pylori infection [68, 76-79]. In a day-to-day routine diagnostic method for $H$. pylori infection, there are some factors including sensitivity, specificity, experience level of experts, stage of diagnosis (pre-treatment or post-treatment stages), technical availability, and costs which are considered to employ a particular test $[70,71,80]$.

\section{Non-invasive diagnostic tests}

Non-invasive assays or non-endoscopic tests are more acceptable and pleasant to individuals; because these tests are cheaper and more comfort and safer in compare with invasive or endoscopic methods. Furthermore, non-invasive techniques are often known as the best choice in epidemiological investigations. Totally, non-endoscopic techniques are recommended for most of the patients with particular situation such as children, pregnant women, and others with any risky condition are recommended for non-invasive diagnostic tools [70, 81-83].

Non-invasive tests are categorized into two main groups of direct and indirect techniques. Stool assay is a direct non-invasive test in which the presence of bacterial antigens is directly evaluated. The assessment of the presence of antibodies or other elements like $\mathrm{CO}_{2}$ due to $\mathrm{H}$. pylori infection is classified as indirect non-invasive techniques including 13C-urea breath test (UBT). The most common non-invasive screening settings of $H$. pylori infection involve UBT and serologic assays. In addition, other reliable tests including stool assay and commercial diagnostic kits are available. However, there are some advantages and disadvantages with each one of the mentioned tools [68, 71, 74, 82].

\section{Non-invasive indirect tests}

\section{Ureolytic-based tests}

13C-urea breath technique. UBT as a direct non-invasive test with diagnostic accuracy of $>95 \%$ (sensitivity $>95 \%$, specificity $>95 \%$ ) is easy to perform and based on urea hydrolysis achieving within gastric mucosal epithelial cells produces ammonia and $\mathrm{CO}_{2}$. In this test, when an individual with $\mathrm{H}$. pylori infection ingests $13 \mathrm{C}$-labeled urea, $H$. pylori as a famous urease enzyme producer breaks down the urea and the labeled $\mathrm{CO}_{2}$ will be monitored within a short time. It takes $2 \mathrm{~h}$ for collecting the breath samples of patients. Also, a single sample is collectible in $40 \mathrm{~min}$ by the help of hyamine as a $\mathrm{CO}_{2}$ trapping agent for exhaling into it. Finally, the percentage of radioactivity of each sample is calculated by a scintillation counter. $13 \mathrm{C}$ has a non-radioactive property; so, the test is safe for children and pregnant women. UBT is occurred in different manners such as mealbased 13C UBT, tablet-based 13C UBT, and 14C UBT. Recently, the tablet-based 
13C UBT is recommended. Different reports confirm UBT as an accessible, accurate, safe, and practical test [70, 73, 83-87].

Serum bicarbonate and ammonia vapor tests. In addition to UBT, there are other ureolytic techniques including serum bicarbonate and ammonia vapor which have their special applications. In serum bicarbonate test, the measure of serum $13 \mathrm{C}$-carbonate is evaluated. This test is reliable and suitable as post-treatment setting.

Ammonia vapor test is used for assessing the level of ammonia gas in the patient breath. This method is absolutely cost effective method [71-88].

\section{Immunologic techniques}

Serological tests. Serological tests are divided into four formats including the enzyme-linked immunosorbent assay (ELISA), agglutination, western blotting, and immunochromatography [70,71,89].

Serological tests regarding $H$. pylori infection diagnosis are designed for detecting specific antibodies such as anti-H. pylori IgG antibodies or anti-CagA and anti-VacA antibodies. In adults, the preferable sample is serum, while in children is saliva or urine. Serologic diagnostic tools are cheap with high limitations. However, the serological tests are common and accessible in a wide range. Depending on the type of serological tests, their sensitivity is up to $90 \%-97 \%$ and the specificity of them varies from $50 \%$ to $96 \%$. Thus, each serological test must be used in validated settings. Some of the serological commercial kits are suitable and available $[68,70,71,73,90]$.

Serological tests are not capable to distinguish active infection from previous contact. Today, serological tests are the third common techniques between non-invasive tools for diagnosing $H$. pylori infection. According to previous reports, the use of combined serological methods may increase the sensitivity and the specificity of the tests $[70,71,73,90,91]$.

Salivary and urinary tests. For decreasing the stressful condition of venepuncture in children, serum test is replaced by saliva or urine tests in children. In comparison with sera samples, the results of salivary antibody assays demonstrated inappropriate sensitivity and specificity; but it seems that the use of special applicators as beneficial device increases the sensitivity and the specificity of the tests $[70,71,92-95]$. Some reports show the preference of urine assay with higher sensitivity and specificity [71, 96, 97].

Near-patient assays. The near-patient assays seem to be an on-site and fast technique with low sensitivity and specificity. Totally, the accuracy of near patient assays is low. The final results vary depending on the condition of whole blood. The whole blood taken from capillary system show different results (sensitivity and specificity) than the venous whole blood because of their various components' 
concentrations. Therefore, the near-patient assays are not recommended when the laboratory-based tests are available [70, 71].

Non-invasive direct tests

Stool antigen test (SAT). The SAT or fecal antigen test (FAT) is known as rapid, simple, and facilitated technique which is based on fecal antigen detection of H. pylori. In new format of the SAT or FAT, polyclonal antibodies are replaced by monoclonal antibodies. The SAT or FAT is divided into two forms of laboratory tests (e.g., ELISA with high accuracy) and speedy in-office tests (e.g., immunochromatographic method with limited accuracy). According to previous reports, the sensitivity as well as the specificity of the SAT or the FAT is $\sim 95 \%$. The SAT or the FAT assays are useful for pre-treatment and posttreatment diagnosis of $H$. pylori infection. The SAT or the FAT tests are improved the level of diagnostics of $H$. pylori infection. Among non-invasive diagnostic techniques, for pre-treatment diagnosis of $H$. pylori infection, the UBT and the SAT (FAT) tests have the same value in accuracy; but for posttreatment diagnosis of $H$. pylori infection, the UBT is the first choice and the SAT (FAT) is the second one [4, 68, 70, 71, 86, 98-102].

\section{Invasive diagnostic tests}

Invasive tests or endoscopic techniques based on biopsy (histology), culture, rapid urease test (RUT), molecular biology, e.g., polymerase chain reaction (PCR) are used for detecting $H$. pylori infection, worldwide. The situation of patients determines the type of invasive tests. An appropriate specimen raises the accuracy of the test $[5,70,83,86]$.

Urease-based assays. Urease tests such as RUT are rapid, cheap with proper accuracy but they have to be validated for different groups of the patients. H. pylori is a typical bacterium, which produces a huge amount of urease enzymes. The biopsy specimen is laid into a buffer free urea solution with a $\mathrm{pH}$ indicator of phenol red. The presence of $H$. pylori in the biopsy may lead to conversion of urea into ammonia and carbon dioxide which in consequence, the $\mathrm{pH}$ raises up and the color of solution start to change. The sensitivity of RUT is $\sim 95 \%$ and the specificity depending on its performance varies from $85 \%$ to $95 \%[4,5,68,70]$.

Histologic-based assays. Histologic techniques indicate a proper evidence of illustrated information through providing sections from gastric mucosa infected by $H$. pylori. The presence of $H$. pylori is distinguished via typical curved appearance of the microorganism on the gastric epithelial cells. The biopsy specimens are stained by different stains including Warthin-Starry silver stain, Giemsa, Genta, 
alcian yellow-toluidine blue, immunochemical stains, and hematoxylin and eosin. The Giemsa stain is more common and it has a sensitivity of $90 \%$. Genta's stain gives a qualified illustration of $H$. pylori and the tissue. The alcian yellowtoluidine blue is a proper stain with the same sensitivity as Giemsa stain. But the former is cheap, facilitated, and gives qualified contrast.

Immunochemical stains with monoclonal antibodies increase the specificity of the histologic tests $[5,70,103-105]$.

It is important to know that the specificity of histologic-based tests is $>95 \%$ while the sensitivity of these tests relying on quality of the biopsy, location of biopsy, size of the biopsy, frequency of the biopsy, and the applied staining varies from $50 \%$ to $95 \%[68,70]$.

Culture-based assays and antimicrobial susceptibility tests. In the most cases, culture tests are used for antibiotic therapy and their applications for clinical diagnostics are rare. Biopsies containing H. pylori must be cultured in the minimum time; because $H$. pylori is very sensitive to environmental factors. The Stuart's transport medium is a suitable choice to recover the bacteria within $24 \mathrm{~h}$ at $4{ }^{\circ} \mathrm{C}$. Mostly biopsies are used for culture media, but oral or fecal specimens may be used rarely. The culture medium of Brain Heart Infusion Agar base comprising blood, starch, charcoal, and bovine serum albumin is used for culture-based tests $[68,70,86]$.

The culture-based tests are mainly used for sensitivity testing of $H$. pylori. The antimicrobial susceptibility tests reveal suitable antibiotics for infection treatment and show the pharmacological resistances. An accurate test may lead to a definite and proper treatment. The common antibiotics which are used for treatment involve amoxicillin, clarithromycin, metronidazole, and tetracycline. Some resistant strains are reported for metronidazole and clarithromycin. Depending on the number of biopsies, culture medium, transport style, and methodology, the sensitivity of culture-based assays varies from $50 \%$ to $95 \%$ while the specificity of these techniques is $>95 \%[68,70,86,106]$.

Molecular biology tests. Molecular biology techniques have a vast range of application from diagnosing to typing. Also, samples may be taken either from cultures or from specimens. Different types of molecular techniques including in situ hybridization, PCR, multiplex-PCR, real-time PCR and DNA microarray can be used in clinical diagnostics. The sensitivity and the specificity of molecular tools are $>95 \%$. Molecular biology tests are often used for identification of antibiotic resistant strains. Among aforementioned molecular diagnostics, DNA microarray is an advanced accurate and rapid diagnostic technique which can be used when there are a huge number of clinical samples. DNA microarray is a powerful technique for detection and identification of drug-resistant and susceptible microbial strains. However, this technique is expensive when the number of clinical specimens is low $[70,86,107-116]$. 
Fluorescent in situ hybridization (FISH). FISH is an accurate, rapid, reliable, sensitive, and specific molecular diagnostic method based on targeting the H. pylori $16 \mathrm{~S}$ rRNA and 23S rRNA genes by fluorescein-labeled oligonucleotide probes. According to previous investigations, FISH is an advanced diagnostic technique with high sensitivity (97\%) and specificity (94\%). Furthermore, this method is able to recognize antimicrobial resistant bacteria and in particular clarithromycin-resistant strains of $H$. pylori. The recognition of clarithromycinresistant and clarithromycin-susceptible strains of $H$. pylori takes only $3 \mathrm{~h}$. However, FISH costs expensive and is not suitable for children and young adults. Until now PCR techniques and in particular real-time PCR are routine clinical methods for detection and identification of drug-resistant and susceptible strains of H. pylori; moreover, real-time PCR is easy to achieve, rapid, with high sensitivity $(98 \%)$ and specificity (92\%). It is also a cost effective technique [117-124].

In recent years, a new developed technique has raised up which is based on FISH and can be performed in the form of in vivo. The method of fluorescence in vivo hybridization (FIVH) is a combined technique consisted of confocal laser microscopy, FISH, and histopathological assays. The preference of this diagnostic technique is the ability of direct observation of live fluorescent $H$. pylori cells as motile and non-motile bacterial cells within mucosal tissues and gastric epithelial cells, respectively. The real time technique of FIVH is an appropriate diagnostic tool for detecting and identifying different type of bacterial cells including H. pylori. There are some limitations for utilizing FIVH as a routine clinical diagnostic tool. Using special parts of the body, the level of $\mathrm{pH}$, the need of confocal laser endomicroscope, and high costs are important limitations for application of FIVH as a routine clinical method. However, there is promising future for FIVH by omitting the aforementioned limitations $[121,125,126]$.

\section{Treatment of $\boldsymbol{H}$. pylori Infection}

There are several pharmaceutical regimens which are used for treating digestive and extra-digestive $H$. pylori infections and diseases. Rapid and accurate diagnosis has an important role for treatment and eradication of $H$. pylori. Because of particular localization of $H$. pylori in gastric mucus layer, there is a need of effective pharmacotherapy. The drugs must be penetrated into gastric mucosal layer to prevent colonization of $H$. pylori. Therefore, monotherapy is not a good choice for complete eradication of $H$. pylori. Even dual therapy is not sharp effective. Mostly, triple treatment including two antimicrobial agents (antibiotics) with a proton-pump inhibitor (PPI) (antisecretory agent) or a bismuth salt is administered. However, quadruple therapy in which two antibiotics, combined 
with a PPI and a bismuth salt is sometimes a suitable alternative for complete treatment of $H$. pylori infection. There are some antibiotics such as clarithromycin, tetracycline, metronidazole, and amoxicillin that have acceptable pure rate for eradication of $H$. pylori. Metronidazole is a proper replacement for amoxicillin in patients that have penicillin allergy. The role of PPIs is to block the $\mathrm{H}^{+}, \mathrm{K}^{+}$ ATPase pump and the bismuth salts have lytic effect on $H$. pylori by disrupting the bacterial cell wall. The effects of dual, triple, and quadruple therapies are $70 \%$, $85 \%$, and $66.7 \%$, respectively. Besides, the side effects of quadruple therapy are more than the other therapies. However, it is an alternative for treatment-resistant strains of $H$. pylori which cause to triple therapy failure [4, 5, 38, 86, 127, 128].

In accordance with a wide range of studies, the prevalence of drug-resistant strains of $H$. pylori is clearly different from a region to another geographic area. But the results indicate a remarkable increase in association with drug resistance rate in many countries. Among a diversity of antibiotics, a significant increase of resistance rate against clarithromycin, levofloxacin, moxifloxacin, and metronidazole has been recognized between $H$. pylori strains. Some reports show the incredible increase of clarithromycin and metronidazole resistance rates up to $80 \%$. On the other hand, the tetracycline and amoxicillin resistance rates are low and insignificant in the majority of geographic areas, but not in Africa. These reports emphasize the increase of pharmacotherapy failures which is related to high general usage of antibiotics around the world. As the drug resistance rates vary from a country to another, a local pharmacotherapy may be a good solution for decreasing the rate of antimicrobial resistance among the strains of $H$. pylori [122, 129-133].

\section{Conclusion}

H. pylori is one of the most important bacteria which may lead to different forms of acute and chronic digestive and extra-digestive infections and diseases. There are several virulence factors that support the level of bacterial pathogenicity. Simultaneously, risk factors in susceptible people may accelerate the progression of $H$. pylori infection. It is important that people with gastrointestinal disorders with or without extra-digestive diseases must be checked and be controlled with intervals.

Always the practical prophylactic health care is the first choice in the field of infectious diseases. Rapid and accurate diagnostics are absolutely determinant factors to control and treat the infection in early stages.

There are various invasive and non-invasive diagnostic methods for detecting $H$. pylori infections and diseases. 
Among non-invasive assays UBT and SAT (FAT) are first-line diagnostic approaches and the serological tests have the low accuracy. However, the availability, cost, and the condition of test performance may differ from place to place. Thus, to improve the diagnostic methods there is no choice rather than combination of two or more techniques with each other.

There are a number of pharmacotherapies, depending on the condition of infections and diseases. Preferably, triple therapy is an appropriate choice but in the presence of drug-resistant strains, quadruple therapy is recommended.

\section{Conflict of Interest}

The authors declare no conflict of interest.

\section{References}

1. Zambon, C. F., Basso, D., Pelloso, M., Tessari, A., Plebani, M.: Pathogenesis of Helicobacter pylori in humans. Hum Emerg Re-Emerg Infect Viral Parasit Infect 1, 607-634 (2016).

2. Marcus, E. A., Sachs, G., Scott, D. R.: Eradication of Helicobacter pylori infection. Curr Gastroenterol Rep 18, 1-9 (2016).

3. Hussain, S., Hamid, S.: Helicobacter pylori in humans: Where are we now? Adv Biomed Res 3, 63 (2014).

4. Prasanthi, C., Prasanthi, N., Manikiran, S., Rao, N. R.: Focus on current trends in the treatment of Helicobacter pylori infection: An update. Int J Pharm Sci Rev Res 9, 42-51 (2011).

5. McColl, K. E.: Helicobacter pylori infection. N Engl J Med 362, 1597-1604 (2010).

6. Farshad, S., Japoni, A., Alborzi, A.: Helicobacter pylori and extradigestive disorders in the past 10 years. Iran Red Crescent Med J 11, 123-132 (2009).

7. Japoni, A., Alborzi, A., Zarenezhad, M., Ranjbar, R.: Changing prevalence of Helicobacter pylori in south of Iran. Iran J Clin Infect Dis 5, 65-69 (2010).

8. Farshad, S., Alborzi, A., Malekhosseini, S., Gramizadeh, B., Oboodi, B., Rasouli, M., Japoni, A., Kalani, M., Pourabbas, B.: Detection of Helicobacter DNA in bile samples of patients with biliary diseases living in south of Iran. Iran J Med Sci 31, 186-190 (2006).

9. Linz, B., Balloux, F., Moodley, Y., Manica, A., Liu, H., Roumagnac, P., Falush, D., Stamer, C., Prugnolle, F., van der Merwe, S. W.: An African origin for the intimate association between humans and Helicobacter pylori. Nature 445, 915-918 (2007).

10. Behzadi, P, Behzadi, E.: Environmental Microbiology, $1^{\text {st }}$ Edition. Niktab Publisher, Tehran, 2007.

11. Ranjbar, R., Khamesipour, F., Jonaidi-Jafari, N., Rahimi, E.: Helicobacter pylori in bottled mineral water: Genotyping and antimicrobial resistance properties. BMC Microbiol 16, 40 (2016). 
12. Malfertheiner, P., Selgrad, M.: Helicobacter pylori infection and current clinical areas of contention. Curr Opin Gastroenterol 26, 618-623 (2010).

13. Tsang, K. W., Lam, S. K.: Helicobacter pylori and extra digestive diseases. J Gastroenterol Hepatol 14, 844-850 (1999).

14. Everhart, J. E.: Recent developments in the epidemiology of Helicobacter pylori. Gastroenterol Clin North Am 29, 559-578 (2000).

15. Woodward, M., Morrison, C., McColl, K.: An investigation into factors associated with Helicobacter pylori infection. J Clin Epidemiol 53, 175-181 (2000).

16. McCallum, R.: Urea protects $H$. (Campylobacter) pylori from the bactericidal effect of acid. Gastroenterology 99, 697-702 (1990).

17. Hsu, P.-I., Yamaoka, Y., Goh, K.-L., Manfredi, M., Wu, D.-C., Mahachai, V.: Helicobacter pylori infection. BioMed Res Int 2015, 278308 (2015).

18. Hu, L., Mobley, H.: Purification and N-terminal analysis of urease from Helicobacter pylori. Infect Immun 58, 992-998 (1990).

19. Phadnis, S. H., Parlow, M. H., Levy, M., Ilver, D., Caulkins, C. M., Connors, J. B., Dunn, B. E.: Surface localization of Helicobacter pylori urease and a heat shock protein homolog requires bacterial autolysis. Infect Immun 64, 905-912 (1996).

20. Smolka, A. J., Backert, S.: How Helicobacter pylori infection controls gastric acid secretion. J Gastroenterol 47, 609-618 (2012).

21. Wroblewski, L. E., Peek, R. M., Wilson, K. T.: Helicobacter pylori and gastric cancer: Factors that modulate disease risk. Clin Microbiol Rev 23, 713-739 (2010).

22. Weeks, D. L., Eskandari, S., Scott, D. R., Sachs, G.: A H ${ }^{+}$-gated urea channel: The link between Helicobacter pylori urease and gastric colonization. Science 287, 482-485 (2000).

23. El-Omar, E. M., Penman, I. D., Ardill, J. E., Chittajallu, R. S., Howie, C., McColl, K. E.: Helicobacter pylori infection and abnormalities of acid secretion in patients with duodenal ulcer disease. Gastroenterology 109, 681-691 (1995).

24. Hansen, S., Melby, K., Aase, S., Jellum, E., Vollset, S.: Helicobacter pylori infection and risk of cardia cancer and non-cardia gastric cancer: A nested case-control study. Scand J Gastroenterol 34, 353-360 (1999).

25. Parsonnet, J., Hansen, S., Rodriguez, L., Gelb, A. B., Warnke, R. A., Jellum, E., Orentreich, N., Vogelman, J. H., Friedman, G. D.: Helicobacter pylori infection and gastric lymphoma. N Engl J Med 330, 1267-1271 (1994).

26. Uemura, N., Okamoto, S., Yamamoto, S., Matsumura, N., Yamaguchi, S., Yamakido, M., Taniyama, K., Sasaki, N., Schlemper, R. J.: Helicobacter pylori infection and the development of gastric cancer. N Engl J Med 345, 784-789 (2001).

27. Nozaki, K., Shimizu, N., Inada, K.-I., Tsukamoto, T., Inoue, M., Kumagai, T., Sugiyama, A., Mizoshita, T., Kaminishi, M., Tatematsu, M.: Synergistic promoting effects of Helicobacter pylori infection and high-salt diet on gastric carcinogenesis in Mongolian gerbils. Cancer Sci 93, 1083-1089 (2002).

28. Romero-Gallo, J., Harris, E. J., Krishna, U., Washington, M. K., Perez-Perez, G. I., Peek, R. M.: Effect of Helicobacter pylori eradication on gastric carcinogenesis. Lab Invest 88, 328-336 (2008).

29. Luther, J., Dave, M., Higgins, P. D., Kao, J. Y.: Association between Helicobacter pylori infection and inflammatory bowel disease: A meta-analysis and systematic review of the literature. Inflammatory Bowel Dis 16, 1077-1084 (2010). 
30. Roesler, B. M., Rabelo-Gonçalves, E. M., Zeitune, J. M.: Virulence factors of Helicobacter pylori: A review. Clin Med Insights Gastroenterol 7, 9 (2014).

31. Naveed, S., Ahmed, S. M., Ali, Z., Awan, R., Zakir, H., Ghazi, L., Nageen, A.: Helicobacter pylori infection. Prof Med J 23, 307-311 (2016).

32. Hong, J.-B., Zuo, W., Wang, A.-J., Lu, N.-H.: Helicobacter pylori infection synergistic with IL-1 $\beta$ gene polymorphisms potentially contributes to the carcinogenesis of gastric cancer. Int J Med Sci 13, 298 (2016).

33. Richy, F., Mégraud, F.: Helicobacter pylori infection as a cause of extra-digestive diseases: Myth or reality? Gastroenterol Clin Biol 27, 459-466 (2003).

34. Xiang, Z., Chen, Y.-P., Ye, Y.-F., Ma, K.-F., Chen, S.-H., Zheng, L., Yang, Y.-D., Jin, X.: Helicobacter pylori and Crohn's disease: A retrospective single-center study from China. World J Gastroenterol 19, 4576 (2013).

35. Franceschi, F., Tortora, A., Gasbarrini, G., Gasbarrini, A.: Helicobacter pylori and extragastric diseases. Helicobacter 19, 52-58 (2014).

36. Jafarzadeh, A., Nemati, M., Rezayati, M. T., Nabizadeh, M., Ebrahimi, M.: Higher serum levels of rheumatoid factor and anti-nuclear antibodies in Helicobacter pylori-infected peptic ulcer patients. Oman Med J 28, 264 (2013).

37. Behzadi, P, Behzadi, E, Ranjbar, R.: Autoimmunity, Crohn's disease and anti-Saccharomyces cerevisiae autoantibodies. Farmacist'ro 156, 50-52 (2014).

38. Kutlubay, Z., Zara, T., Engin, B., Serdaroglu, S., Tüzün, Y., Yilmaz, E., Eren, B.: Helicobacter pylori infection and skin disorders. Hong Kong Med J 20, 317-324 (2014).

39. Hosseinzadeh, M., Khosravi, A., Saki, K., Ranjbar, R.: Evaluation of Helicobacter pylori infection in patients with common migraine headache. Arch Med Sci 7, 844-849 (2011).

40. Izadi, M., Fazel, M., Sharubandi, S. H., Saadat, S. H., Farahani, M. M., Nasseri, M. H., Dabiri, H., SafiAryan, R., Esfahani, A. A., Ahmadi, A.: Helicobacter species in the atherosclerotic plaques of patients with coronary artery disease. Cardiovasc Pathol 21, 307-311 (2012).

41. Delitala, A. P., Pes, G. M., Malaty, H. M., Pisanu, G., Delitala, G., Dore, M. P.: Implication of cytotoxic Helicobacter pylori infection in autoimmune diabetes. J Diabetes Res 501, 7347065 (2016).

42. Behzadi, P., Behzadi, E., Ranjbar, R.: The incidence and prevalence of Crohn's disease in global scale. SOJ Immunol 3, 1-6 (2015).

43. Dossumbekova, A., Prinz, C., Gerhard, M., Brenner, L., Backert, S., Kusters, J. G., Schmid, R. M., Rad, R.: Helicobacter pylori outer membrane proteins and gastric inflammation. Gut 55, 1360-1361 (2006).

44. de Negreiros Bessa, P. P., Barbosa, F. C., do Carmo, A. P. S., Furtado, G. B., Barroso, F. C., Rabenhosrt, S. H. B.: Presence of the genes $\operatorname{cag} A, \operatorname{cag} E$, virB11 and allelic variation of vacA of Helicobacter pylori are associated with the activity of gastritis. Open $\mathrm{J}$ Gastroenterol 4, 347 (2014).

45. Hosseini, E., Poursina, F., Van de Wiele, T., Safaei, H. G., Adibi, P.: Helicobacter pylori in Iran: A systematic review on the association of genotypes and gastroduodenal diseases. J Res Med Sci 17, 280 (2012).

46. Shiota, S., Watada, M., Matsunari, O., Iwatani, S., Suzuki, R., Yamaoka, Y.: Helicobacter pylori iceA, clinical outcomes, and correlation with cagA: A meta-analysis. PLoS One 7, e30354 (2012). 
47. Farshad, S., Alborzi, A., Abbasian, A.: Association of H. pylori virulence genes CagA, $V a c A$ and $U r e A B$ with ulcer and nonulcer diseases in Iranian population. Pak J Biol Sci 10, 1185-1189 (2007).

48. Boncristiano, M., Paccani, S. R., Barone, S., Ulivieri, C., Patrussi, L., Ilver, D., Amedei, A., D'Elios, M. M., Telford, J. L., Baldari, C. T.: The Helicobacter pylori vacuolating toxin inhibits $\mathrm{T}$ cell activation by two independent mechanisms. J Exp Med 198, 1887-1897 (2003).

49. Phadnis, S. H., Ilver, D., Janzon, L., Normark, S., Westblom, T. U.: Pathological significance and molecular characterization of the vacuolating toxin gene of Helicobacter pylori. Infect Immun 62, 1557-1565 (1994).

50. Gebert, B., Fischer, W., Weiss, E., Hoffmann, R., Haas, R.: Helicobacter pylori vacuolating cytotoxin inhibits T lymphocyte activation. Science 301, 1099-1102 (2003).

51. Pakbaz, Z., Shirazi, M. H., Ranjbar, R.: Frequency of sabA gene in Helicobacter pylori strains isolated from patients in Tehran, Iran. Iran Red Crescent Med J 15, 767 (2013).

52. Ghasemi, A., Shirazi, M., Ranjbar, R., Khorramizadeh, M., Daryani, N., Hosseini, M.: The prevalence of cagA and cagE genes in Helicobacter pylori strains isolated from different patient groups by polymerase chain reaction. Pak J Biol Sci 11, 2579-2583 (2008).

53. Akopyants, N. S., Clifton, S. W., Kersulyte, D., Crabtree, J. E., Youree, B. E., Reece, C., Bukanov, N. O., Drazek, E. S., Roe, B. A., Berg, D. E.: Analyses of the cag pathogenicity island of Helicobacter pylori. Mol Microbiol 28, 37-53 (1998).

54. Censini, S., Lange, C., Xiang, Z., Crabtree, J. E., Ghiara, P., Borodovsky, M., Rappuoli, R., Covacci, A.: cag, a pathogenicity island of Helicobacter pylori, encodes type I-specific and disease-associated virulence factors. Proc Natl Acad Sci U S A 93, 14648-14653 (1996).

55. Blaser, M. J., Perez-Perez, G. I., Kleanthous, H., Cover, T. L., Peek, R. M., Chyou, P., Stemmermann, G. N., Nomura, A.: Infection with Helicobacter pylori strains possessing $\operatorname{cag} A$ is associated with an increased risk of developing adenocarcinoma of the stomach. Cancer Res 55, 2111-2115 (1995).

56. Asahi, M., Azuma, T., Ito, S., Ito, Y., Suto, H., Nagai, Y., Tsubokawa, M., Tohyama, Y., Maeda, S., Omata, M.: Helicobacter pylori CagA protein can be tyrosine phosphorylated in gastric epithelial cells. J Exp Med 191, 593-602 (2000).

57. Odenbreit, S., Püls, J., Sedlmaier, B., Gerland, E., Fischer, W., Haas, R.: Translocation of Helicobacter pylori CagA into gastric epithelial cells by type IV secretion. Science 287, 1497-1500 (2000).

58. Ohnishi, N., Yuasa, H., Tanaka, S., Sawa, H., Miura, M., Matsui, A., Higashi, H., Musashi, M., Iwabuchi, K., Suzuki, M., Yamada, G., Azuma, T., Hatakeyama, M.: Transgenic expression of Helicobacter pylori CagA induces gastrointestinal and hematopoietic neoplasms in mouse. Proc Natl Acad Sci U S A 105, 1003-1008 (2008).

59. van Doorn, L. J., Figueiredo, C., Sanna, R., Plaisier, A., Schneeberger, P., de Boer, W., Quint, W.: Clinical relevance of the cagA, vacA, and iceA status of Helicobacter pylori. Gastroenterology 115, 58-66 (1998).

60. Farshad, S., Japoni, A., Alborzi, A., Hosseini, M.: Restriction fragment length polymorphism of virulence genes cagA, vacA and ureAB of Helicobacter pylori strains isolated from Iranian patients with gastric ulcer and nonulcer disease. Saudi Med J 28, 529 (2007).

61. Ranjbar, R., Khamesipour, F., Jonaidi Jafari, N., Rahimi, E.: Helicobacter pylori isolated from Iranian drinking water: vacA, cagA, iceA, oipA and $b a b A 2$ genotype status and antimicrobial resistance properties. FEBS Open Bio 6, 433-441 (2016). 
62. Souod, N., Kargar, M., Doosti, A., Ranjbar, R., Sarshar, M.: Genetic analysis of cagA and vacA genes in Helicobacter pylori isolates and their relationship with gastroduodenal diseases in the west of Iran. Iran Red Crescent Med J 15, 371 (2013).

63. Boren, T., Falk, P., Roth, K., Larson, G., Normark, S.: Attachment of Helicobacter pylori to human gastric epithelium mediated by blood group antigens. Science 262, 1892-1895 (1993).

64. Yamaoka, Y., Kwon, D. H., Graham, D. Y.: A $M_{\mathrm{r}} 34,000$ proinflammatory outer membrane protein (oipA) of Helicobacter pylori. Proc Natl Acad Sci U S A 97, 7533-7538 (2000).

65. Yamaoka, Y., Ojo, O., Fujimoto, S., Odenbreit, S., Haas, R., Gutierrez, O., El-Zimaity, H. M. T., Reddy, R., Arnqvist, A., Graham, D. Y.: Helicobacter pylori outer membrane proteins and gastroduodenal disease. Gut 55, 775-781 (2006).

66. Snaith, A., El-Omar, E. M.: Helicobacter pylori: Host genetics and disease outcomes. Expert Rev Gastroenterol Hepatol 2, 577-585 (2008).

67. Farshad, S., Rasouli, M., Jamshidzadeh, A., Hosseinkhani, A., Japoni, A., Alborzi, A., Taghavi, A., Asl, H. K., Ranjbar, R.: IL-1 $\beta$ (+3953 C/T) and IL-8 (-251 A/T) gene polymorphisms in $H$. pylori mediated gastric disorders. Iran J Immunol 7, 96108 (2010).

68. Bytzer, P., Dahlerup, J. F., Eriksen, J. R., Jarbøl, D., Rosenstock, S., Wildt, S.: Diagnosis and treatment of Helicobacter pylori infection. Dan Med Bull 58, C4271 (2011).

69. Ricci, C., Holton, J., Vaira, D.: Diagnosis of Helicobacter pylori: Invasive and noninvasive tests. Best Pract Res Clin Gastroenterol 21, 299-313 (2007).

70. Vaira, D., Holton, J., Menegatti, M., Ricci, C., Gatta, L., Geminiani, A., Miglioli, M.: Invasive and non-invasive tests for Helicobacter pylori infection. Aliment Pharmacol Ther 14, 13-22 (2000).

71. Gatta, L., Ricci, C., Tampieri, A., Vaira, D.: Non-invasive techniques for the diagnosis of Helicobacter pylori infection. Clin Microbiol Infect 9, 489-496 (2003).

72. Shahidi, M. A., Fattahi, M. R., Farshad, S., Alborzi, A.: Validation of an in-house made rapid urease test kit against the commercial CLO-test in detecting Helicobacter pylori infection in the patients with gastric disorders. J Res Med Sci 17, 212 (2012).

73. Malfertheiner, P., Megraud, F., O’Morain, C., Bazzoli, F., El-Omar, E., Graham, D., Hunt, R., Rokkas, T., Vakil, N., Kuipers, E. J.: Current concepts in the management of Helicobacter pylori infection: The Maastricht III Consensus Report. Gut 56, 772-781 (2007).

74. Islam, M., Rahman, S., Shamsuzzaman, S., Muazzam, N., Kibria, S., Hossain, M., Ahmed, N., Sarkar, A., Nahar, S.: A comparative study among different invasive methods for the diagnosis of Helicobacter pylori. Faridpur Med Coll J 5, 21-24 (2010).

75. Mégraud, F.: How should Helicobacter pylori infection be diagnosed? Gastroenterology 113, S93-S98 (1997).

76. Sondergaard, B., Bytzer, P.: Helicobacter pylori infection is no longer the major cause of peptic ulcer in Copenhagen County. Helicobacter 10, 484 (2005).

77. Bytzer, P., Teglbjærg, P. S.: Helicobacter pylori-negative duodenal ulcers: Prevalence, clinical characteristics, and prognosis - Results from a randomized trial with 2-year follow-up. Am J Gastroenterol 96, 1409-1416 (2001).

78. Aro, P., Storskrubb, T., Ronkainen, J., Bolling-Sternevald, E., Engstrand, L., Vieth, M., Stolte, M., Talley, N. J., Agréus, L.: Peptic ulcer disease in a general adult population the 
Kalixanda study: A random population-based study. Am J Epidemiol 163, 1025-1034 (2006).

79. Gisbert, J. P., Calvet, X., Feu, F., Bory, F., Cosme, A., Almela, P., Santolaria, S., Aznárez, R., Castro, M., Fernández, N.: Eradication of Helicobacter pylori for the prevention of peptic ulcer rebleeding. Helicobacter 12, 279-286 (2007).

80. Briggs, A., Sculpher, M., Logan, R., Aldous, J., Ramsay, M., Baron, J.: Cost effectiveness of screening for and eradication of Helicobacter pylori in management of dyspeptic patients under 45 years of age. BMJ 312, 1321-1325 (1996).

81. Isaacson, P., Spencer, J.: Gastric lymphoma and Helicobacter pylori. Important Adv Oncol, 111-121 (1996).

82. Vaira, D., Stanghellini, V., Menegatti, M., Palli, D., Corinaldesi, R., Miglioli, M.: Prospective screening of dyspeptic patients by Helicobacter pylori serology: A safe policy? Endoscopy 29, 595-601 (1997).

83. Suerbaum, S., Michetti, P.: Helicobacter pylori infection. N Engl J Med 347, 1175-1186 (2002).

84. Moayyedi, P., Braunholtz, D., Heminbrough, E., Clough, M., Tompkins, D. S., Mapstone, N. P., Mason, S., Dowell, A. C., Richards, G. I., Chalmers, D. M.: Do patients need to fast for a 13C-urea breath test? Eur J Gastroenterol Hepatol 9, 275-277 (1997).

85. Hamlet, A., Stage, L., Lönroth, H., Cahlin, C., Nyström, C., Pettersson, A.: A novel tabletbased 13C urea breath test for Helicobacter pylori with enhanced performance during acid suppression therapy. Scand J Gastroenterol 34, 367-374 (1999).

86. Malfertheiner, P., Megraud, F., O’Morain, C. A., Atherton, J., Axon, A. T., Bazzoli, F., Gensini, G. F., Gisbert, J. P., Graham, D. Y., Rokkas, T.: Management of Helicobacter pylori infection - The Maastricht IV/Florence consensus report. Gut 61, 646-664 (2012).

87. Gisbert, J., Pajares, J.: Review article: 13C-urea breath test in the diagnosis of Helicobacter pylori infection - A critical review. Aliment Pharmacol Ther 20, 1001-1017 (2004).

88. Dun, C., Blac, M., Cowell, D., Penaul, C., Ratcliffe, N. M., Spence, R., Teare, C.: Ammonia vapour in the mouth as a diagnostic marker for Helicobacter pylori infection: Preliminary 'proof of principle' pharmacological investigations. Br J Biomed Sci 58, 66 (2001).

89. Rahimi, H. R., Rasouli, M., Jamshidzadeh, A., Farshad, S., Firoozi, M. S., Taghavi, A. R., Kiany, S.: New immunological investigations on Helicobacter pylori-induced gastric ulcer in patients. Microbiol Immunol 57, 455-462 (2013).

90. Laheij, R., Straatman, H., Jansen, J., Verbeek, A.: Evaluation of commercially available Helicobacter pylori serology kits: A review. J Clin Microbiol 36, 2803-2809 (1998).

91. Fusconi, M., Vaira, D., Menegatti, M., Farinelli, S., Figura, N., Holton, J., Ricci, C., Corinaldesi, R., Miglioli, M.: Anti-CagA reactivity in Helicobacter pylori-negative subjects (a comparison of three different methods). Dig Dis Sci 44, 1691-1695 (1999).

92. Luzza, F., Imeneo, M., Marasco, A., Crotta, S., Ierardi, E., Usai, P., Virgilio, C., Nardone, G., Marchi, S., Sanna, G.: Evaluation of a commercial serological kit for detection of salivary immunoglobulin G to Helicobacter pylori: A multicentre study. Eur J Gastroenterol Hepatol 12, 1117-1120 (2000).

93. Loeb, M. B., Riddell, R. H., James, C., Hunt, R., Smaill, F. M.: Evaluation of salivary antibodies to detect infection with Helicobacter pylori. Can J Gastroenterol 11, 437-440 (1996). 
94. Christie, J., McNulty, C., Shepherd, N., Valori, R.: Is saliva serology useful for the diagnosis of Helicobacter pylori? Gut 39, 27-30 (1996).

95. Malaty, H. M., Logan, N. D., Graham, D. Y., Ramchatesingh, J. E., Reddy, S. G.: Helicobacter pylori infection in asymptomatic children: Comparison of diagnostic tests. Helicobacter 5, 155-159 (2000).

96. Miwa, H., Hirose, M., Kikuchi, S., Terai, T., Iwazaki, R., Kobayashi, O., Takei, Y., Ogihara, T., Sato, N.: How useful is the detection kit for antibody to Helicobacter pylori in urine (URINELISA) in clinical practice? Am J Gastroenterol 94, 3460-3463 (1999).

97. Graham, D., Reddy, S.: Rapid detection of anti-Helicobacter pylori IgG in urine using immunochromatography. Aliment Pharmacol Ther 15, 699-702 (2001).

98. Gisbert, J. P., de la Morena, F., Abraira, V.: Accuracy of monoclonal stool antigen test for the diagnosis of Helicobacter pylori infection: A systematic review and meta-analysis. Am J Gastroenterol 101, 1921-1930 (2006).

99. Deguchi, R., Matsushima, M., Suzuki, T., Mine, T., Fukuda, R., Nishina, M., Ozawa, H., Takagi, A.: Comparison of a monoclonal with a polyclonal antibody-based enzyme immunoassay stool test in diagnosing Helicobacter pylori infection after eradication therapy. J Gastroenterol 44, 713-716 (2009).

100. Shimoyama, T., Kato, C., Kodama, M., Kobayashi, I., Fukuda, Y.: Applicability of a monoclonal antibody-based stool antigen test to evaluate the results of Helicobacter pylori eradication therapy. Jpn J Infect Dis 62, 225-227 (2009).

101. Calvet, X., Lario, S., Ramírez Lázaro, M. J., Montserrat, A., Quesada, M., Reeves, L., Masters, H., Suárez Lamas, D., Gallach, M., Miquel, M.: Accuracy of monoclonal stool tests for determining cure of Helicobacter pylori infection after treatment. Helicobacter 15, 201-205 (2010).

102. Schwarzer, A., Lottspeich, C., Rüssmann, H., Ossiander, G., Koletzko, S.: Evaluation of a novel rapid one-step monoclonal chromatographic immunoassay for detection of Helicobacter pylori in stool from children. Eur J Clin Microbiol Infect Dis 26, 475-480 (2007).

103. Laine, L., Lewin, D. N., Naritoku, W., Cohen, H.: Prospective comparison of H\&E, Giemsa, and Genta stains for the diagnosis of Helicobacter pylori. Gastrointest Endosc 45, $463-467$ (1997).

104. Rotimi, O., Cairns, A., Gray, S., Moayyedi, P., Dixon, M.: Histological identification of Helicobacter pylori: Comparison of staining methods. J Clin Pathol 53, 756-759 (2000).

105. El-Zimaity, H. M.: Accurate diagnosis of Helicobacter pylori with biopsy. Gastroenterol Clin North Am 29, 863-869 (2000).

106. Farshad, S., Alborzi, A., Japoni, A., Ranjbar, R., Asl, K. H., Badiee, P., Shahidi, M. A., Hosseini, M.: Antimicrobial susceptibility of Helicobacter pylori strains isolated from patients in Shiraz, Southern Iran. World J Gastroenterol 16, 5746 (2010).

107. Zhou, J.: Microarrays for bacterial detection and microbial community analysis. Curr Opin Microbiol 6, 288-294 (2003).

108. Farshad, S., Rasouli, M., Alborzi, A.: Simultaneous detection of Helicobacter genus and Helicobacter pylori species using a multiplex PCR method. Iran Biomed J 8, 205-209 (2004).

109. Behzadi, P., Ranjbar, R., Alavian, S. M.: Nucleic acid-based approaches for detection of viral hepatitis. Jundishapur J Microbiol 8, e17449 (2015). 
110. Behzadi, P, Behzadi, E, Ranjbar, R.: The application of microarray in medicine. ORL'ro 24, 24-26 (2014).

111. Behzadi, P, Behzadi, E, Ranjbar, R.: Microarray probe set: Biology, bioinformatics and biophysics. Albanian Med J 2, 78-83 (2015).

112. Behzadi, P, Behzadi, E, Ranjbar, R.: Basic Modern Molecular Biology, $1^{\text {st }}$ Edition. Persian Science \& Research Publisher, Tehran, 2014.

113. Jahandeh, N., Ranjbar, R., Behzadi, P., Behzadi, E.: Uropathogenic Escherichia coli virulence genes: Invaluable approaches for designing DNA microarray probes. Cent European J Urol 68, 452-458 (2015).

114. Behzadi, P., Behzadi, E., Ranjbar, R.: IL-12 family cytokines: General characteristics, pathogenic microorganisms, receptors, and signalling pathways. Acta Microbiol Immunol Hung 63, 1-25 (2016).

115. Behzadi, P., Najafi, A., Behzadi, E., Ranjbar, R.: Microarray long oligo probe designing for Escherichia coli: An in-silico DNA marker extraction. Cent Eur J Urol 69, 105-111 (2016).

116. Behzadi, P, Ranjbar, R.: Microarray long oligo probe designing for Bacteria: An in silico pan-genomic research. Albanian Med J 2, 5-11 (2016).

117. Miftahussurur, M., Yamaoka, Y.: Diagnostic methods of Helicobacter pylori infection for epidemiological studies: Critical importance of indirect test validation. BioMed Res Int 2016, 4819423 (2016).

118. Tajbakhsh, S., Samarbaf-Zadeh, A. R., Moosavian, M.: Comparison of fluorescent in situ hybridization and histological method for the diagnosis of Helicobacter pylori in gastric biopsy samples. Med Sci Monit 14, BR183-BR187 (2008).

119. McNulty, C. A., Lehours, P., Megraud, F.: Diagnosis of Helicobacter pylori infection. Helicobacter 16, 10-18 (2011).

120. Garza-González, E., Perez-Perez, G. I., Maldonado-Garza, H. J., Bosques-Padilla, F. J.: A review of Helicobacter pylori diagnosis, treatment, and methods to detect eradication. World J Gastroenterol 20, 1438-1449 (2014).

121. Xuan, S.-H., Wu, L.-P., Zhou, Y.-G., Xiao, M.-B.: Detection of clarithromycin-resistant Helicobacter pylori in clinical specimens by molecular methods: A review. J Global Antimicrob Resist 4, 35-41 (2016).

122. Thung, I., Aramin, H., Vavinskaya, V., Gupta, S., Park, J., Crowe, S., Valasek, M.: Review article: The global emergence of Helicobacter pylori antibiotic resistance. Aliment Pharmacol Ther 43, 514-533 (2016).

123. Cattoir, V., Nectoux, J., Lascols, C., Deforges, L., Delchier, J.-C., Megraud, F., Soussy, C.-J., Cambau, E.: Update on fluoroquinolone resistance in Helicobacter pylori: New mutations leading to resistance and first description of a gyrA polymorphism associated with hypersusceptibility. Int J Antimicrob Agents 29, 389-396 (2007).

124. Moore, R. A., Beckthold, B., Wong, S., Kureishi, A., Bryan, L. E.: Nucleotide sequence of the gyrA gene and characterization of ciprofloxacin-resistant mutants of Helicobacter pylori. Antimicrob Agents Chemother 39, 107-111 (1995).

125. Fontenete, S., Leite, M., Guimarães, N., Madureira, P., Ferreira, R. M., Figueiredo, C., Wengel, J., Azevedo, N. F.: Towards fluorescence in vivo hybridization (FIVH) detection of $H$. pylori in gastric mucosa using advanced LNA probes. PLoS One 10, e0125494 (2015). 
126. Fontenete, S., Leite, M., Cappoen, D., Santos, R., Van Ginneken, C., Figueiredo, C., Wengel, J., Cos, P., Azevedo, N. F.: Fluorescence in vivo hybridization (FIVH) for detection of Helicobacter pylori infection in a C57BL/6 mouse model. PLoS One 11, e0148353 (2016).

127. Kusters, J. G., van Vliet, A. H., Kuipers, E. J.: Pathogenesis of Helicobacter pylori infection. Clin Microbiol Rev 19, 449-490 (2006).

128. Mégraud, F.: Rationale for the choice of antibiotics for the eradication of Helicobacter pylori. Eur J Gastroenterol Hepatol 7, S49 (1995).

129. Gao, W., Cheng, H., Hu, F., Li, J., Wang, L., Yang, G., Xu, L., Zheng, X.: The evolution of Helicobacter pylori antibiotics resistance over 10 years in Beijing, China. Helicobacter 15, 460-466 (2010).

130. Zhang, Y.-X., Zhou, L.-Y., Song, Z.-Q., Zhang, J.-Z., He, L.-H., Ding, Y.: Primary antibiotic resistance of Helicobacter pylori strains isolated from patients with dyspeptic symptoms in Beijing: A prospective serial study. World J Gastroenterol 21, 2786 (2015).

131. De Francesco, V., Giorgio, F., Hassan, C., Manes, G., Vannella, L., Panella, C., Ierardi, E., Zullo, A.: Worldwide H. pylori antibiotic resistance: A systematic. J Gastrointest Liver Dis 19, 409-414 (2010).

132. Karpiński, T. M., Andrzejewska, E., Eder, P., Linke, K., Szkaradkiewicz, A.: Evaluation of antimicrobial resistance of Helicobacter pylori in the last 15 years in West Poland. Acta Microbiol Immunol Hung 62, 287-293 (2015).

133. Torres, J., Camorlinga-Ponce, M., Pérez-Pérez, G., Madrazo-De la Garza, A., Dehesa, M., González-Valencia, G., Muñoz, O.: Increasing multidrug resistance in Helicobacter pylori strains isolated from children and adults in Mexico. J Clin Microbiol 39, 2677-2680 (2001). 